\title{
THE EFFECT OF TILLAGE AND WHEAT RESIDUE MANAGEMENT ON NITROGEN UPTAKE EFFICIENCY AND NITROGEN HARVEST INDEX IN WHEAT
}

\author{
Elnaz EBRAHIMIAN ${ }^{1}$, Alireza KOOCHEKI ${ }^{1 *}$, Mehdi NASSIRI MAHALLATI ${ }^{I}$, Surur KHORRAMDEL ${ }^{1}$ \\ Alireza BEHESHTI ${ }^{2}$ \\ ${ }^{1}$ Ferdowsi University of Mashhad, Faculty of Agriculture, Department of Agronomy, Mashhad, IRAN \\ ${ }^{2}$ Agricultural and Natural Resources Research Center of Khorasan Razavi Province, IRAN \\ ${ }^{*}$ Corresponding author: akooch@um.ac.ir
}

Received: 10.06.2016

\begin{abstract}
In order to evaluate the effects of tillage and wheat residue management on nitrogen uptake and distribution, nitrogen uptake efficiency, nitrogen use efficiency and nitrogen harvest index in wheat, a two-year field experiment was implemented as a split block experiment in a randomized complete block design with twenty treatments and three replicates at experimental site of Ferdowsi University of Mashhad, Iran in 2013 and 2014 growing seasons. Four different tillage practices namely, conventional tillage applied by mouldboard plough + disk, reduced tillage practices applied by sweep plough + disk and chisel plough + disk and conserved tillage applied by disk as vertical factor and five different crop residue applications $(0,25,50,75$ and $100 \%$ wheat residue) as horizontal factor. According to the results, the lowest $(2.58 \%)$ and highest $(2.77 \%)$ grain nitrogen percentage were observed when disk and chisel plough + disk were used, respectively. Employing chisel plough + disk led to the maximum nitrogen uptake efficiency and nitrogen use efficiency. Grain nitrogen percentage, nitrogen uptake efficiency and nitrogen use efficiency significantly increased with increasing wheat residue level. For instance, when wheat residue was applied at $75 \%$ ratio, nitrogen uptake efficiency increased by $61.2 \%$ compared with control treatment. According to the results it appears that application of wheat residue along with reduced tillage could improve nitrogen utilization efficiency, especially in arid and semi-arid regions.
\end{abstract}

Keywords: Nitrogen harvest index, Nitrogen uptake efficiency, Nitrogen use efficiency, Reduced tillage, Residue management, Wheat.

\section{INTRODUCTION}

Nitrogen is the most important of all major nutrients and plays a key role in photosynthesis, vegetative growth and protein synthesis in wheat (Salvagiotti et al., 2009). Accordingly, nitrogen fertilizers, whether applied as organic materials or as mineral nitrogen, are therefore a key element to gain maximum yield and improve final product quality in wheat production (Kazemzadeh and Peighambar Doust, 2013). Unfortunately, nitrogen fertilizers are often used more than optimized limit, which not only increase production costs but also create critical environmental problems (Guarda et al., 2004; Zheng et al., 2007). Nitrogen loss in wheat is not limited to field, a considerable amount of nitrogen loss occurs after harvest and during processing and consumption of the crop (Koocheki et al., 2012; Hu et al., 2014). It has been reported that increase in nitrogen loss is more likely when mineral fertilizers are used (Soltani et al., 2013). Therefore, choosing fertilizer type and proper fertilizer management could result in lower nitrogen loss (Soltani et al., 2013). Consequently, determining required nitrogen, particularly from organic sources to gain maximum economic yield and reduce nitrogen loss should be taken into account more than ever (Ankumah et al., 2003).

Nitrogen use efficiency is defined as $\mathrm{kg}$ of yield per $\mathrm{kg}$ consumed fertilizer which represents the ability of the crops to take available nitrogen and turn it to economic yield (Salvagiotti et al., 2009). Nitrogen use efficiency is defined by interactions between its components such as nitrogen uptake efficiency (quotient of plant nitrogen uptake and total crop nitrogen supply) and physiological nitrogen use efficiency (quotient of yield and uptake nitoegn) (Lea and Azevedo, 2006; Salvagiotti et al., 2009).

Increase in nitrogen use efficiency is one of the most important strategies for increasing agricultural production and reducing environmental pollution (Limon-Ortega et al., 2008; Koocheki et al., 2012). According to Moraghebi et al. (2011), grain yield, grain protein content and grain protein yield in wheat linearly increased with increasing nitrogen application, however, nitrogen use efficiency and physiological nitrogen use efficiency significantly decreased. In addition to nitrogen use efficiency, nitrogen 
harvest index (an indicator of the up-taking nitrogen transformed into the biomass of the usable plant organs) could help to understand the relationships between quality and nitrogen application (Salvagiotti et al., 2009; Koochei and Seyyedi, 2015).

Conservation tillage, which is based on zero or reduced tillage practices, and maintaining crop residues on soil surface, play a critical role in improving soil fertilization (Ghuman and Sur, 2001; Rezvani Moghaddam et al., 2013; Faligowska and Szukała, 2015) by increasing soil organic matter and nutrients availability, especially nitrogen (De Gryze et al., 2005; Liu et al., 2006; Singh and Haile, 2007). Furthermore, considering the positive effects of crop residue in stimulating microbial activity, improving soil structure and permeability and reducing water erosion (De Gryze et al., 2005; Monzon et al., 2006; Bastian et al., 2009), it seems that application of crop residue would improve nitrogen uptake efficiency and nitrogen use efficiency through increasing nitrogen availability and reducing nitrogen leaching. In this context, it has been reported that application of mushroom waste medium could increase growth characteristics, yield and nitrogen uptake by wheat (Seyyedi and Rezvani Moghaddam, 2011).

The aim the current study was to evaluate the effects of tillage and wheat residue management on nitrogen uptake and distribution, nitrogen uptake efficiency, nitrogen use efficiency and nitrogen harvest index in wheat.

\section{MATERIALS AND METHODS}

The experiments were carried out during 2013 and 2014 growing seasons as a split block experiment in a randomized complete block design with twenty treatments and three replicates at experimental site of Ferdowsi University of Mashhad, Iran. The average monthly rainfall and temperature are given in Table 3.

Prior to the experiment, soil samples were randomly collected across the field from $0-30 \mathrm{~cm}$ depth to determine physical and chemical properties. The results are given in Table 4.

The experimental treatments consisted of twenty combinations of two factors: four different tillage practices namely, conventional tillage applied by mouldboard plough + disk, two reduced tillage practices applied by sweep plough + disk and chisel plough + disk and conserved tillage applied by disk as vertical factor and five different crop residue applications $(0,25,50,75$ and $100 \%$ wheat residue) as horizontal factor.

In the first year, the required amount of wheat residue (5250 kg ha-1) was determined based on the straw and stubble produced by local farmers (Table 5). The wheat residue were imported to the field and incorporated into the soil at the depth of $30 \mathrm{~cm}$ just after performing tillage practices on $21^{\text {st }}$ of May. In the second year, the amount of applied wheat residue was determined based on the produced straw and stubble from the first year and then incorporated into the soil on June $20^{\text {th }}$ as mentioned above.
Each experimental plot was $3 \times 3 \mathrm{~m}$ consisted of 6 rows spaced $0.5 \mathrm{~m}$ apart. One $\mathrm{m}$ distance between the blocks and between each plot was considered to prevent lateral water movement and other interferences.

Winter wheat (Triticum aestivum c.v Cascogen) seeds were sown on $11^{\text {th }}$ and $16^{\text {th }}$ of November in the first and second year, respectively. The plant density of 200 plants per $\mathrm{m}^{2}$ was selected. The furrow irrigation was performed immediately after seed sowing. Polyethylene pipelines and a water counters were installed to control irrigation water. During crop growth period no chemical fertilizer, herbicide or pesticide were applied. Weeds were removed manually.

At maturity stage, when all the plants turned yellow ( $20^{\text {th }}$ of June in 2013 and $23^{\text {rd }}$ of June in 2014) the crop was harvested and grain yield and biological yield were determined. In addition, nitrogen uptake efficiency, nitrogen used efficiency and nitrogen harvest index were calculated using following equations:

Equation 1: Grain nitrogen content $\left(\mathrm{g} \mathrm{m}^{-2}\right)=$ Grain weight $\left(\mathrm{g} \mathrm{m}^{-2}\right) \times$ Grain nitrogen percentage

Equitation 2: Plant nitrogen content $\left(\mathrm{g} \mathrm{m}^{-2}\right)=$ Plant weight $\left(\mathrm{g} \mathrm{m}^{-2}\right) \times$ Plant nitrogen percentage

Equation 3: Nitrogen uptake efficiency $(\%)=$ Plant nitrogen content/Soil nitrogen content $\times 100$

Equation 4: Nitrogen use efficiency ( $g$ grain g nitrogen in the soil $)=$ Grain yield $/$ Soil nitrogen content

Equation 5: Nitrogen harvest index $(\%)=$ Grain nitrogen content/ Plant nitrogen content $\times 100$

Nitrogen percentage in different part of plant was determined using micro-kjeldahl method (AOAC, 2000).

Four soil samples were collected from each plot using an auger. The data were obtained by averaging out four obtained data for each plot. Soil nitrogen content was calculated based on the soil nitrogen content before initiating the experiment and added nitrogen due to wheat residue per unit area.

All data were subjected to analysis of variance (ANOVA) using SAS software (version 9.3). When an $F$ test indicated statistical significance at $P<0.01$ or $P<0.05$, the protected least significant difference test (protected LSD) was used to separate the means of main effect.

\section{RESULTS AND DISCUSSION}

\section{Nitrogen percentage in different parts of wheat}

The results indicated that grain, straw and root nitrogen percentage was significantly affected by tillage practices and crop residue levels. However, interaction between tillage practices and crop residue levels was not statistically significant on these parameters (Table 1). In addition, the main effect of year, interaction between year and tillage practices and interaction between year and crop residue levels were not significant (Table 1). 
According to the results, chisel plough + disk treatment was more effective in increasing grain, straw and root nitrogen content compared with the other tillage practices (Table 2). For example, chisel plough + disk treatment increased nitrogen percentage in grain and straw by 7.4 and $14 \%$, respectively, compared with mouldboard plough + disk treatment (Table 2). From the results, grain, straw and root nitrogen percentage increased with increasing wheat residue rate (Table 2). However, there was no significant difference between 75 and $100 \%$ wheat residue treatments in terms of grain, straw and root nitrogen percentage (Table 2 ). For instance, grain nitrogen percentage increased by $32 \%$ due to application of $75 \%$ wheat residue treatment compared with control treatment (Table 2).

Generally, increases in soil aggregate stability, soil water content and organic matter and nutrients are the main benefits of conservation tillage (Hobbs et al., 2008; Thierfelder and Wall, 2010; Farooq et al., 2011). Hence, the combination of these benefits can lead to increase in nitrogen uptake by plants through increasing nitrogen availability and stimulating plant growth. On the other hand, since chisel plough does not turn the soil, so water and nutrients loss as well as soil structure disturbance would be at a minimum compared with mouldboard plough (Azim Zadeh et al., 2002; Mazaheri and Majnon Hoseini, 2007). Accordingly, increase in nitrogen uptake in wheat might be due to improved soil quality in terms of nutrients availability and lower nitrogen loss.

\section{Nitrogen uptake in different parts of wheat}

From the results given in Table 1, the main effects of tillage practice and wheat residue levels were found to be significant on grain, straw and plant nitrogen content. Moreover, except for plant nitrogen content, none of these parameters were affected by interaction between tillage practices and wheat residue levels (Table 1). Furthermore, the main effect of year, interaction between year and tillage practices and interaction between year and crop residue levels were not significant (Table 1).

The results revealed that the highest and lowest grain, straw and plant nitrogen content were observed when chisel plough + disk and disk practices were applied, respectively (Table 2). In comparison with mouldboard plough + disk, grain, straw and plant nitrogen content was significantly higher when chisel plough + disk practice was applied. Similar to nitrogen percentage, nitrogen content in grain, straw, root and plant significantly increased with increasing wheat residue levels up to $75 \%$. The lowest nitrogen content was observed in control treatment (Table 2). The maximum absorbed nitrogen in wheat plants $\left(30.4 \mathrm{~g} \mathrm{~m}^{-2}\right)$ was obtained when chisel plough + disk was accompanied $75 \%$ of with wheat residue (Figure 1 ).

In general, nutrient availability due to gradual mineralization of organic nitrogen during growing season is known as the most important advantages of crop residues application, (Azadshahraki et al., 2011; Li et al., 2015).
Hence, according to equations 1 and 2, increase in nitrogen uptake per unit area, not only can be affected by nitrogen uptake by plants, but also might be due to more vegetative growth and seed weight per unit area. In this regard, increase in leaf area index and dry matter production in barley due to wheat residue application has been documented by Sadeghi and Kazemeini (2011).

During decomposition of crop residue with high carbon to nitrogen ratio, soil nitrogen is consumed by microorganisms, which might result in reduced availability of nitrogen for the plants (Foroughifar and Poor-Kasmani, 2002; Ruffo and Bollero, 2003). In the current study, wheat reside were applied before seed sowing in summer, therefore increase in dry matter production and nitrogen uptake was mainly due to gradual release of elements from the decomposed wheat residue and microorganisms. As mentioned earlier, reduction soil disturbance, wind and water erosion and nutrients loss, which are the main benefits of conservation tillage (Farooq et al., 2011), can lead to increase plant growth, grain yield and nitrogen uptake per unit area. In other words, retaining crop residue not only improves physical and chemical properties of soil, but also promotes soil biological activity thought increasing microorganisms population, as a result, more nutrients will be available for the plants during growing season (Shams Abadi and Rafiee, 2007; Salehi et al., 2011). Similar results have been reported by Ozpinar and Cay (2066) who stated that reduced tillage plays a pivotal role in increasing soil organic matter and nitrogen. Increase in wheat grain yield on account of chisel plough compare with mouldboard has been reported by the other researchers (Shams Abadi and Rafiee, 2007; Mohammadi et al., 2009).

\section{Nitrogen uptake and nitrogen use efficiency}

Nitrogen uptake and nitrogen use efficiency significantly affected by tillage practice and wheat residue levels (Table 1). The interaction between tillage practices and wheat residue levels was significant on nitrogen uptake efficiency (Table 1). The main effect of year, interaction between year and tillage practices and interaction between year and crop residue levels were not significant on nitrogen uptake and nitrogen use efficiency (Table 1).

The maximum nitrogen uptake efficiency (64.21 g grain per $g$ nitrogen) and nitrogen use efficiency (17.48 g grain per $g$ nitrogen) were related to chisel plough + disk tillage practice (Table 2). For instance, nitrogen uptake and nitrogen use efficiency increased by 20.7 and $16.1 \%$ due to chisel plough + disk tillage practice compared with mouldboard plough + disk tillage practice (Table 2). Nitrogen uptake and nitrogen use efficiency both increased with increasing wheat residue application up to $75 \%$ and then slightly decreased by applying $100 \%$ wheat residue treatment, however this reduction was not statistically significant (Table 2). In addition, the maximum nitrogen uptake efficiency $(78.52 \%)$ was related to chisel plough + disk tillage practice along with $75 \%$ wheat residue treatment (Figure 2). 
Table 1. Analysis of variance (mean of squares) on wheat characteristics affected by tillage practices and wheat reside levels.

\begin{tabular}{|c|c|c|c|c|c|c|c|c|c|c|c|}
\hline S.O.V & DF & $\begin{array}{l}\text { N percentage } \\
\text { in seed }\end{array}$ & $\begin{array}{l}\mathbf{N} \text { percentage } \\
\text { in residue }\end{array}$ & $\begin{array}{l}\text { N percentage } \\
\text { in root }\end{array}$ & $\begin{array}{l}\mathbf{N} \text { content } \\
\text { in seed }\end{array}$ & $\begin{array}{l}N \text { content } \\
\text { in residue }\end{array}$ & $\begin{array}{l}\mathbf{N} \text { content } \\
\text { in root }\end{array}$ & $\begin{array}{c}\mathbf{N} \text { content } \\
\text { in total } \\
\text { plant }\end{array}$ & $\begin{array}{l}\text { N uptake } \\
\text { efficiency }\end{array}$ & $\begin{array}{c}\mathrm{N} \text { use } \\
\text { efficiency }\end{array}$ & $\begin{array}{l}\mathbf{N} \text { harvest } \\
\text { index }\end{array}$ \\
\hline Year (Y) & 1 & NS & NS & NS & NS & NS & NS & NS & NS & NS & NS \\
\hline $\mathrm{Y}$ in Block & 4 & - & - & - & - & - & - & - & - & - & - \\
\hline Tillage (T) & 3 & $* *$ & $* *$ & $* *$ & $* *$ & $* *$ & NS & $* *$ & $* *$ & $* *$ & NS \\
\hline $\mathrm{Y} \times \mathrm{T}$ & 3 & NS & NS & NS & NS & NS & NS & NS & NS & NS & NS \\
\hline $\begin{array}{l}\mathrm{Y} \times \mathrm{T} \text { in } \\
\text { Block }\end{array}$ & 12 & - & - & - & - & - & - & - & - & - & - \\
\hline $\begin{array}{l}\text { Levels of } \\
\text { residue }(S)\end{array}$ & 4 & $* *$ & $* *$ & $* *$ & $* *$ & $* *$ & $* *$ & $* *$ & $* *$ & $* *$ & NS \\
\hline $\mathrm{Y} \times \mathrm{S}$ & 4 & NS & NS & NS & NS & NS & NS & NS & NS & NS & NS \\
\hline $\mathrm{T} \times \mathrm{S}$ & 12 & NS & NS & NS & NS & NS & NS & $*$ & $*$ & NS & NS \\
\hline $\mathrm{Y} \times \mathrm{T} \times \mathrm{S}$ & 12 & NS & NS & NS & NS & NS & NS & NS & NS & NS & NS \\
\hline Error & 64 & - & - & - & - & - & - & - & - & - & - \\
\hline
\end{tabular}

*** and ns: significant at the 0.05 and 0.01 levels of probability and no significant, respectively.

Table 2. Main effects of tillage practices and wheat residue levels on different wheat characteristics.

\begin{tabular}{|c|c|c|c|c|c|c|c|c|c|c|}
\hline $\begin{array}{l}\text { Experimental } \\
\text { treatments }\end{array}$ & $\begin{array}{l}\mathrm{N} \text { percentage } \\
\text { in seed }\end{array}$ & $\begin{array}{l}\mathrm{N} \text { percentage } \\
\text { in residue }\end{array}$ & $\begin{array}{l}\mathrm{N} \text { percentage } \\
\text { in root }\end{array}$ & $\begin{array}{l}N \text { content in } \\
\text { seed }\left(g \cdot \mathbf{~ m}^{-2}\right)\end{array}$ & $\begin{array}{l}\mathbf{N} \text { content in } \\
\text { residue (g. } \mathbf{m}^{-} \\
{ }_{2} \text { ) }\end{array}$ & $\begin{array}{l}\mathrm{N} \text { content in } \\
\operatorname{root}\left(\mathrm{g} \cdot \mathrm{m}^{-2}\right)\end{array}$ & $\begin{array}{l}\mathbf{N} \text { content in } \\
\text { total plant (g. } \\
\left.\mathbf{m}^{-2}\right)\end{array}$ & $\begin{array}{l}\text { N uptake } \\
\text { efficiency } \\
(\%)\end{array}$ & $\begin{array}{c}\text { N use } \\
\text { efficiency } \\
(\%)\end{array}$ & $\begin{array}{l}\mathrm{N} \text { harvest } \\
\text { index }(\%)\end{array}$ \\
\hline \multicolumn{11}{|l|}{ Tillage } \\
\hline Disk (D) & 2.58 & 0.43 & 0.45 & 12.79 & 4.03 & 1.07 & 17.90 & 47.22 & 12.97 & 70.99 \\
\hline Sweep + D & 2.57 & 0.42 & 0.45 & 15.60 & 4.03 & 1.09 & 20.72 & 54.65 & 15.86 & 74.75 \\
\hline Mouldboard + D & 2.58 & 0.43 & 0.45 & 15.08 & 4.25 & 1.12 & 20.46 & 53.19 & 15.06 & 72.93 \\
\hline Chisel + D & 2.77 & 0.49 & 0.47 & 18.77 & 4.78 & 1.15 & 24.70 & 64.21 & 17.48 & 75.74 \\
\hline $\mathrm{LSD}=0.05$ & 0.087 & 0.036 & 0.004 & 1.523 & 0.517 & 0.108 & 1.343 & 3.482 & 1.388 & 6.221 \\
\hline \multicolumn{11}{|l|}{$\begin{array}{l}\text { Levels of residue } \\
(\%)\end{array}$} \\
\hline 0 & 2.19 & 0.36 & 0.41 & 11.26 & 3.20 & 0.91 & 15.37 & 41.34 & 13.85 & 73.06 \\
\hline 25 & 2.44 & 0.43 & 0.43 & 12.82 & 3.84 & 0.98 & 17.64 & 46.87 & 13.91 & 72.17 \\
\hline 50 & 2.72 & 0.47 & 0.46 & 15.27 & 4.75 & 1.19 & 21.20 & 55.63 & 14.67 & 71.54 \\
\hline 75 & 2.89 & 0.48 & 0.49 & 19.88 & 4.68 & 1.19 & 25.75 & 66.79 & 17.82 & 76.67 \\
\hline 100 & 2.89 & 0.48 & 0.49 & 18.57 & 4.91 & 1.27 & 24.75 & 63.44 & 16.46 & 74.57 \\
\hline $\mathrm{LSD}=0.05$ & 0.097 & 0.041 & 0.004 & 1.702 & 0.578 & 0.120 & 1.501 & 3.893 & 1.551 & 6.602 \\
\hline \multicolumn{11}{|l|}{ Year } \\
\hline First & 2.62 & 0.44 & 0.46 & 15.29 & 4.21 & 1.08 & 20.58 & 54.28 & 15.20 & 73.70 \\
\hline Second & 2.62 & 0.44 & 0.46 & 15.83 & 4.34 & 1.14 & 21.31 & 55.36 & 15.48 & 73.51 \\
\hline $\mathrm{LSD}=0.05$ & 0.062 & 0.026 & 0.003 & 1.077 & 0.365 & 0.076 & 0.950 & 2.462 & 0.981 & 3.278 \\
\hline
\end{tabular}


Table 3. Some meteorological data for the two growing seasons.

\begin{tabular}{|c|c|c|c|c|}
\hline \multirow{2}{*}{ Month } & \multicolumn{2}{|c|}{ Precipitation (mm) } & \multicolumn{2}{|c|}{ Average temperature $\left({ }^{\circ} \mathrm{C}\right)$} \\
\hline & 2013-2014 & $2014-2015$ & $2013-2014$ & $2014-2015$ \\
\hline November & 3.30 & 42.50 & 9.83 & 7.28 \\
\hline December & 7.30 & 11.30 & 3.73 & 5.95 \\
\hline January & 6.00 & 21.90 & 4.93 & 5.06 \\
\hline February & 1.40 & 54.70 & 1.69 & 7.77 \\
\hline March & 85.10 & 41.10 & 9.21 & 8.39 \\
\hline April & 34.40 & 7.60 & 17.01 & 17.94 \\
\hline May & 27.40 & 24.10 & 22.82 & 23.02 \\
\hline June & 3.70 & 0.00 & 27.26 & 28.35 \\
\hline Total & 168.60 & 203.20 & - & \\
\hline Average & - & - & 12.06 & 12.97 \\
\hline
\end{tabular}

Table 4. Some of physical and chemical properties of field soil in the experiment.

\begin{tabular}{|c|c|c|c|c|c|c|}
\hline $\begin{array}{l}\text { Soil } \\
\text { texture }\end{array}$ & $\begin{array}{c}\text { Available N (mg kg- } \\
\left.{ }_{1}^{-}\right)\end{array}$ & $\begin{array}{c}\text { Available P (mg kg- } \\
1 \text { ) }\end{array}$ & $\begin{array}{c}\text { Available K (mg kg- } \\
\left.1_{1}^{-}\right)\end{array}$ & $\begin{array}{l}\mathrm{OC} \\
(\%)\end{array}$ & pH & $\begin{array}{c}\mathrm{EC}\left(\mathrm{dS} \mathrm{m} \mathrm{m}^{-}\right. \\
1)\end{array}$ \\
\hline Silty-loam & 17.41 & 8.43 & 142.31 & 0.43 & 8.24 & 1.09 \\
\hline
\end{tabular}

Table 5. Some nutrient content in wheat residue used in the experiment.

\begin{tabular}{cccc}
\hline OC (\%) & Total N (\%) & Total P (\%) & Total K (\%) \\
\hline 35.02 & 0.47 & 0.27 & 0.62 \\
\hline
\end{tabular}

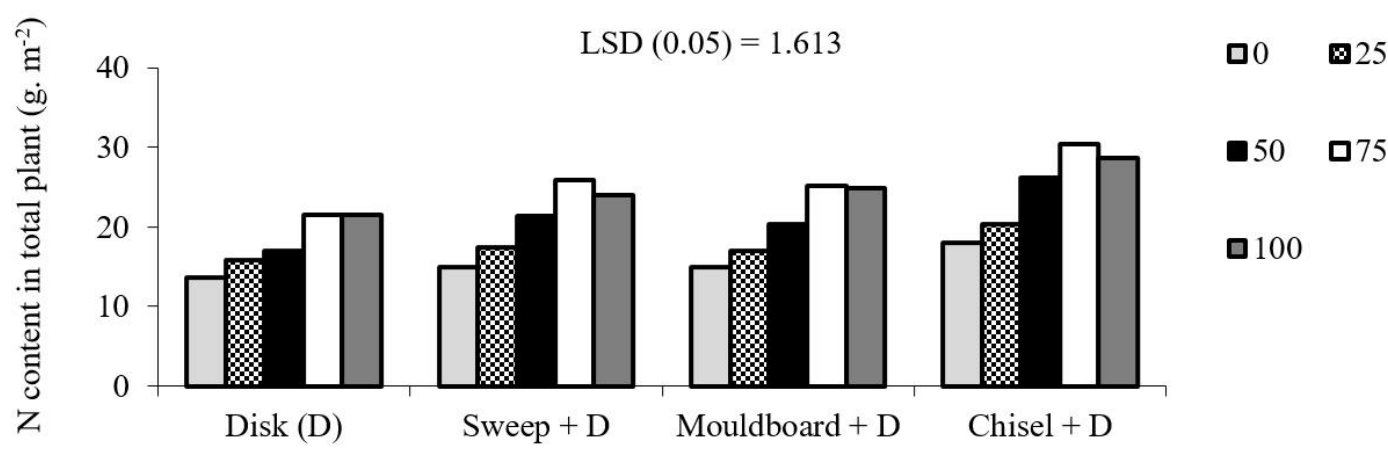

Tillage systems

Figure 1. Interaction between tillage practices and wheat residue on plant nitrogen content.

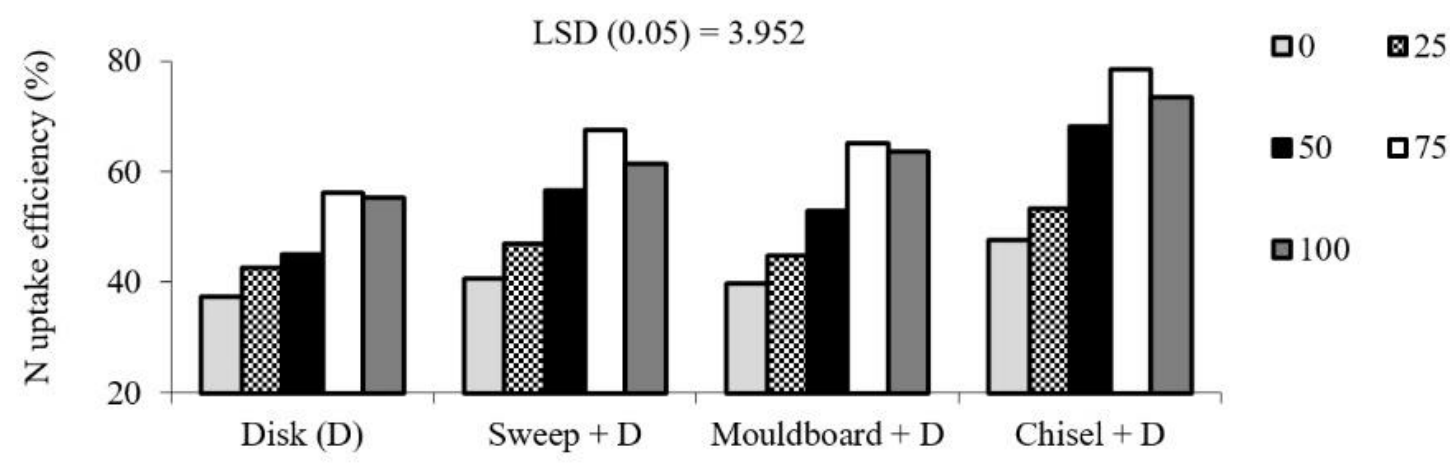

Tillage systems

Figure 2. Interaction between tillage practices and wheat residue on nitrogen uptake efficiency.

As mentioned before, increase in nutrient availability is the most outstanding benefits of reduced tillage along with retaining crop residue. According to equations 3 and 4 , increase in nitrogen availability or increase in grain yield 
per unit area can result in increase in nitrogen uptake and nitrogen use efficiency (Yolcu and Cetin, 2015). On the other hand, due to positive relationships between total nitrogen content in plant and nitrogen uptake efficiency (Figure 3) as well as between nitrogen uptake efficiency and nitrogen use efficiency (Figure 4), it seems that factors can result in increase in nitrogen uptake, in turn, lead to an increased grain yield for each consumed nitrogen unit.

\section{Nitrogen harvest index}

Nitrogen harvest index was not affected by year, interaction between year and tillage practices as well as interaction between year and wheat residue levels (Table 1). It appears that nitrogen harvest index is controlled by genetic factors than environmental conditions or agronomic practices (Salvagiotti et al., 2009).

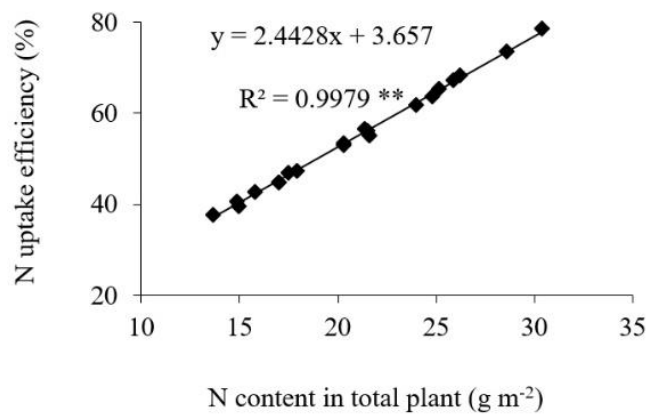

Figure 3. Relationships between nitrogen content in plant and nitrogen uptake efficiency.

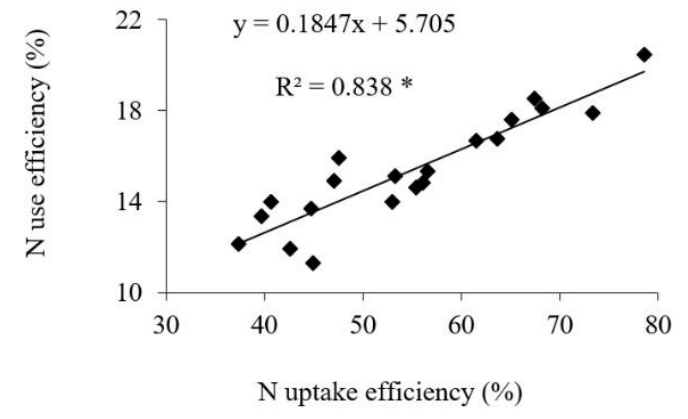

Figure 4. Relationships between nitrogen uptake efficiency and nitrogen use efficiency.

\section{ACKNOWLEDGMENTS}

The authors acknowledge the financial support of this project (grant number 3/31223) by Vice President for Research and Technology, Ferdowsi University of Mashhad, Iran.

\section{CONCLUSIONS}

According to the results, it can be concluded that reduced tillage using chisel plough and disk plays a key role in improving nitrogen uptake and nitrogen use efficiency. Hence, application of wheat residue and reduced tillage are recommended to increase suitability in wheat production in arid and semi-arid regions. In addition, the results indicated that more application of wheat residue $(100 \%$ wheat residue) not only had no positive effect on nitrogen uptake, but also decreased nitrogen uptake and nitrogen use efficiency. Therefore, in order to increase nitrogen use efficiency and to reduce production costs and environmental pollution, suitable amount of wheat residue should be applied.

\section{LITERATURE CITED}

Ankumah, R.O, V. Khan, K. Mwamba and K. Kpomblekou-A. 2003. The influence of source and timing of nitrogen fertilizers on yield and nitrogen use efficiency of four sweet potato cultivars. Agric. Ecosyst. Environ. 100: 201-207.

AOAC. 2000. Official methods of analysis (17th ed.) Gaithersburg, Maryland, USA: Association of Official Analytical Chemists.

Azadshahraki, F., H. Naghavi and H. Najafinejad. 2011. Effect of tillage method and wheat residual management on some soil properties and grain corn yield in Kerman, Iran. J. New Agric. Sci., 6: 1-9.

Azim Zadeh, S.M., A. Koocheki and M. Bala. 2002. Effect of different tillage methods on bulk density, proposity, soil moisture content and yield of wheat under dryland conditions. Iran. J. Crop Sci., 3: 209-224.

Bastian, F., L. Bouziri, B. Nicolardot and L. Ranjard. 2009. Impact of wheat straw decomposition on successional patterns of soil microbial community structure. Soil Biol. Biochem., 41: 262-275.

De Gryze, S., J. Six, C. Brits and R. Merckx. 2005. A quantification of short-term macro aggregate dynamics: influences of wheat residue input and texture. Soil Biol. Biochem., 37: 55-66.

Faligowska, A. and Szukała J. 2015. The effect of various longterm tillage systems on yield and yield component of yellow and narrow-leaved lupin. Turk. J. Field Crops, 20, 188-193.

Farooq, M., K.C. Flower, K. Jabran, A. Wahid and K.H.M. Siddique. 2011. Crop yield and weed management in rainfed conservation agriculture. Soil Tillage Res., 117: 172-183.

Foroughifar, H. and M.E. Poor-Kasmani. 2002. Soil Science and Management. Ferdowsi University of Mashhad Press.

Ghuman. B.S. and H.S. Sur. 2001. Tillage and residue management effects on soil properties in a direct drill tillage system. Soil Tillage Res., 42: 209-219.

Guarda, G., S. Padovan and G. Delogu. 2004. Grain yield, nitrogen-use efficiency and baking quality of old and modern Italian bread-wheat cultivars grown at different nitrogen levels. Eur. J. Agron., 21: 181-192.

Hobbs, P.R., K. Sayre and R. Gupta. 2008. The role of conservation agriculture in sustainable agriculture. Philosophic. Trans. Royal Soc. London, 363: 543-555.

Hu, D., Z. Sun, T. Li, H. Yan and H. Zhang. 2014. Nitrogen nutrition index and its relationship with $\mathrm{N}$ use efficiency, tuber yield, radiation use efficiency, and leaf parameters in potatoes. J. Int. Agric., 13: 1008-1016.

Kazemzadeh, M. and S.H. Peighambar Doust. 2013. Effect of organic and nitrogen fertilizers on physicochemical properties and bread-making quality of wheat (Triticum aestivum cv. Alvand). J. Food Res., 23: 179-197.

Koocheki, A. and S.M. Seyyedi. 2015. Relationship between nitrogen and phosphorus use efficiency in saffron (Crocus sativus L.) as affected by mother corm size and fertilization. Ind. Crops Prod., 71: 128-137.

Koocheki, A., M. Nassiri Mahallati, H. Mansoori and R. Moradi. 2012. Assessment of nitrogen flow and use efficiency in the course of production to utilization for wheat (Triticum aestivum L.) and maize (Zea mays L.) in Iran. J. Agroecol., 4: 192-200. 
Lea, P.J. and R.A. Azevedo. 2006. Nitrogen use efficiency. 1. Uptake of nitrogen from the soil. Ann. App. Biol., 149: 243247.

Li, J., Y. Li, X. Yang, J. Zhang, Z. Lin and B. Zhao. 2015. Microbial community structure and functional metabolic diversity are associated with organic carbon availability in an agricultural soil. J. Int. Agric., 14: 2500-2511.

Limon-Ortega, A., B. Govaerts and K.D. Sayre. 2008. Straw management, crop rotation, and nitrogen source effect on wheat grain yield and nitrogen use efficiency. Eur. J. Agron., 29: 21-28.

Liu, X., S.J. Herbert, A.M. Hashemi, X. Zhang and G. Ding. 2006. Effects of agricultural management on soil organic matter and carbon transformation - a review. Plant Soil Environ., 52: 531-543.

Mazaheri, D. and N. Majnon Hoseini. 2007. Fundamental of Agronomy. Tehran University Press.

Mohammadi, K., K. Nabi Allahi, M. Agha Alikhani and F. Khormali. 2009. Study on the effect of different tillage methods on the soil physical properties, yield and yield components of rainfed wheat. J. Plant Prod., 16: 77-91.

Monzon, J.P, V.O. Sadras and F.H. Andrade. 2006. Fallow soil evaporation and water storage as affected by stubble in subhumid (Argentina) and semi-arid (Australia) environments. Field Crops Res., 98: 83-90.

Moraghebi, F., M. Akbari Famileh and A. Houshmandfar. 2011. The effect of amount and time of nitrogen use on the percentage of grain protein and efficiency use of Nitrogen of the Pishtaz cultivar wheat in Saveh region. J. Plants Ecosyst., 7: 65-76.

Ozpinar, S. and A. Cay. 2006. Effect of different tillage systems on the quality and crop productivity of a clay-loam soil in semi-arid North-Western Turkey. Soil Tillage Res., 88: 95106.

Rezvani Moghaddam, P., A. Koocheki, A. Molafilabi and S.M. Seyyedi. 2013. The effects of different levels of applied wheat straw in different dates on saffron (Crocus sativus L.) daughter corms and flower initiation criteria in the second year. Saffron Agron. Technol., 1: 55-70.

Ruffo, M.L. and G.A. Bollero. 2003. Residue decomposition and prediction of carbon and nitrogen release rates based on biochemical fraction using principle - component regression. Agron. J., 95: 1034-1040.
Sadeghi, H. and S.A. Kazemeini. 2011. An investigation on physiological characteristics of tow barley (Hordeum vulgare L.) cultivars and soil moisture content as affected by straw management and nitrogen rates under dryland conditions. Iran. J. Field Crops Res., 9: 544-556.

Salehi, F., M.J. Bahrani, S.A. Kazemaini, H. Pakniyat and N.A. Karimian. 2011. Effects of wheat residue and nitrogen fertilizer rate on some soil properties in common Bean cultivation. J. Sci. Technol. Agric. Nat. Res., 25: 209-218.

Salvagiotti, F., J.M. Castellarín, D.J. Miralles and H.M. Pedrol. 2009. Sulfur fertilization improves nitrogen use efficiency in wheat by increasing nitrogen uptake. Field Crop Res., 113: $170-177$.

Seyyedi, S.M. and P. Rezvani Moghaddam. 2011. Yield, yield components and nitrogen use efficiency of wheat (Triticum aestivum L.) in mushroom compost, biological fertilizer and urea application. J. Agroecol., 3: 313-323.

Shams Abadi, H.A. and S. Rafiee. 2007. Study on the effect of tillage practices and different seed densities on yield of rainfed wheat. J. Agric. Sci. Nat. Res., 13: 95-102.

Singh, B.R. and M. Haile. 2007. Impact of tillage and nitrogen fertilization on yield, nitrogen use efficiency of tef (Eragrostis tef (Zucc.) Trotter) and soil properties. Soil Tillage Res., 94: $55-63$.

Soltani, E., A. Soltani, E. Zeinali and A. Dastmalchi. 2013. Simulation of nitrogen losses under wheat production in Gorgan, using CROPSYST model. Water Soil Con., 20: 146163.

Thierfelder, C. and P.C. Wall. 2010. Rotation in conservation agriculture systems of Zambia: effects on soil quality and water relations. Exp. Agric., 46: 309-325.

Yolcu, R. and Cetin, O. 2015. Nitrogen fertigation to improve nitrogen use efficiency and crude protein on silage corn. Turk. J. Field Crops, 20, 233-241.

Zheng, Y.M., Y.F. Ding, Q.S. Wang, G.H. Li, H. Wu, Q. Yuan, H.Z. Wang and S.H. Wang. 2007. Effect of nitrogen applied before transplanting on NUE in rice. Agric. Sci. China, 6: 842848. 